\title{
Changing Health Care in the United States
}

\author{
by Dallas Salisbury*
}

\section{Introduction}

Health care in the United States is undergoing great change. That change is being driven by (1) concern over the cost of health care and (2) concern over the fact that many individuals do not have access to care, in spite of the high level of national spending on health care.

What might be termed a pulic - private partnership for meeting the health care challenge is taking on clearer form in the United States. Government policy is reinforcing the responsibility of employers to provide health protection for active workers and their dependents. At the same time, policy is moving to expand the level of government responsibility for meeting the needs of retirees and others outside the workforce. For those without health insurance publicly sponsored risk pools are being formed, and the Federal government is contemplating making health insurance a right that goes along with any job. A key difference from other nations: a focus on financing and delivery through the private sector.

\section{Paying for Health Care}

Health related expenditures reached $\$ 425$ billion in the United States in 1985 . This represented $10.7 \%$ of the US Gross National Product, the highest level ever (or, just over $\$ 1721$ per person).

Consumers directly paid $\$ 119$ billion or $28 \%$; private insurance paid $\$ 133.3$ billion or $31 \%$; State and local governments paid $\$ 50.4$ billion or $12 \%$; and, the Federal government paid $\$ 125.4$ billion or $29 \%$. The largest expenditures were for hospital stays $(39 \%)$, then other personal health $(21 \%)$, physician services $(20 \%)$, other national health expenditures $(12 \%)$, and nursing home $(8 \%)$.

Private health insurance continued its ten year climb in the percent of private expenditures, compared to out-of pocket, and Federal financing has also increased due to rapid expansion of the Federal Medicare program for the elderly.

* President EBRI, Employee Benefit Research Institute, $2121 \mathrm{~K}$ Street, Washington DC. This paper is based on two reports presented for the Geneva Association, in Paris on December 4, 1986 and in Berlin on June 15, 1987. 
Table 1 : Nonelderly Population by Selected Sources of Health Insurance Coverage and Own Work Status, 1985

\begin{tabular}{|c|c|c|c|c|c|}
\hline \multirow[b]{2}{*}{$\begin{array}{l}\text { Own work } \\
\text { status }\end{array}$} & \multirow[b]{2}{*}{ Total } & \multicolumn{3}{|c|}{ Insured Population } & \multirow{2}{*}{$\begin{array}{l}\text { No Health } \\
\text { Insurance } \\
\text { Coverage }\end{array}$} \\
\hline & & $\begin{array}{c}\text { Employer- } \\
\text { provided }\end{array}$ & $\begin{array}{l}\text { Other } \\
\text { private }\end{array}$ & Public & \\
\hline & \multicolumn{5}{|c|}{ (in millions) } \\
\hline Total & 199.8 & 131.8 & 23.0 & 23.9 & 34.8 \\
\hline \multicolumn{6}{|l|}{ Family Head } \\
\hline Workers & 78.8 & 53.6 & 10.0 & 8.7 & 12.3 \\
\hline \multicolumn{6}{|l|}{ Other Family } \\
\hline Workers & 44.5 & 34.0 & 4.8 & 2.1 & 6.8 \\
\hline Nonworkers & 76.5 & 44.3 & 8.2 & 13.1 & 15.6 \\
\hline Children & 56.4 & 34.9 & 4.1 & 9.1 & 11.1 \\
\hline \multirow[t]{2}{*}{ Others } & 20.2 & 9.4 & 4.1 & 4.0 & 4.6 \\
\hline & \multicolumn{5}{|c|}{ (percent within source of coverage groups) } \\
\hline Total & $100.0 \%$ & $100.0 \%$ & $100.0 \%$ & $100.0 \%$ & $100.0 \%$ \\
\hline \multicolumn{6}{|l|}{ Family Head } \\
\hline Workers & $39.4 \%$ & $40.7 \%$ & $43.5 \%$ & $36.4 \%$ & $35.3 \%$ \\
\hline \multicolumn{6}{|l|}{ Other Family } \\
\hline Workers & $22.3 \%$ & $25.8 \%$ & $20.9 \%$ & $8.8 \%$ & $19.5 \%$ \\
\hline Nonworkers & $38.3 \%$ & $33.6 \%$ & $35.7 \%$ & $54.8 \%$ & $44.8 \%$ \\
\hline Children & $28.2 \%$ & $26.5 \%$ & $17.8 \%$ & $38.1 \%$ & $31.9 \%$ \\
\hline \multirow[t]{2}{*}{ Others } & $10.1 \%$ & $7.1 \%$ & $17.8 \%$ & $16.7 \%$ & $13.2 \%$ \\
\hline & \multicolumn{5}{|c|}{ (percent within worker categories) } \\
\hline Total & $100.0 \%$ & $66.0 \%$ & $11.5 \%$ & $12.0 \%$ & $17.4 \%$ \\
\hline \multicolumn{6}{|l|}{ Family Head } \\
\hline Workers & $100.0 \%$ & $68.0 \%$ & $12.7 \%$ & $11.0 \%$ & $15.6 \%$ \\
\hline \multicolumn{6}{|l|}{ Other Family } \\
\hline Workers & $100.0 \%$ & $76.4 \%$ & $10.8 \%$ & $4.7 \%$ & $15.3 \%$ \\
\hline Nonworkers & $100.0 \%$ & $57.9 \%$ & $10.7 \%$ & $17.1 \%$ & $20.4 \%$ \\
\hline Children & $100.0 \%$ & $61.9 \%$ & $7.3 \%$ & $16.1 \%$ & $19.7 \%$ \\
\hline Others & $100.0 \%$ & $46.5 \%$ & $20.3 \%$ & $19.8 \%$ & $22.8 \%$ \\
\hline
\end{tabular}

Source : Employee Benefit Research Institute tabulations of the March 1986 Current Population Survey. 
Employer plans are the largest source of health insurance coverage in the United States. EBRI tabulations of the March 1986 Current Population Survey indicate that $66 \%$ of all Americans under age 65 had employer-provided coverage (see Table 1). Among fulltime workers employed for at least 35 weeks, employer-provided health coverage was $75.9 \%$. Nearly $12 \%$ of the under- 65 population reported coverage from either Medicare, Medicaid, or CHAMPUS (Civilian Health and Medical Program of the Uniformed Services); $11.5 \%$ reported private individual coverage. However, $17.4 \%$ of the population under age 65 did not have any coverage. These people totaled more than 35 million in number. EBRI tabulations show that over two-thirds of those without health insurance protection had family income of less than $\$ 20,000$ in 1985 , which was less than the average national wage (see Table 2). As noted, finding a way to provide insurance protection for these "uncovered" Americans is high national priority.

The population of the United States is aging, as in other nations. Health needs, and thus cost, generally increase with age, creating the added challenge of a near certain increase in total health care spending as the average age and the number of very old continue to climb.

Table 2 : Nonelderly Population by Selected Sources of Health Insurance Coverage and Family Income, 1985

\begin{tabular}{|c|c|c|c|c|c|c|}
\hline \multirow[b]{2}{*}{ Family Income } & \multirow[b]{2}{*}{ Total } & \multicolumn{4}{|c|}{$\begin{array}{c}\text { Insured Population : Private \& Public } \\
\text { Employer provided }\end{array}$} & \multirow{2}{*}{$\begin{array}{l}\text { No Health } \\
\text { Insurance } \\
\text { Coverage }\end{array}$} \\
\hline & & Total & Total & Direct & Indirect & \\
\hline Total & 199.8 & 165.8 & 131.8 & 68.3 & 63.5 & 34.8 \\
\hline less than $\$ 10,000$ & 31.7 & 19.7 & 4.5 & 2.9 & 1.6 & 12.0 \\
\hline$\$ 10,000$ - 19,999 & 37.6 & 27.5 & 20.2 & 11.7 & 8.5 & 10.0 \\
\hline$\$ 20,000-29,999$ & 38.1 & 32.9 & 28.7 & 14.5 & 14.2 & 5.2 \\
\hline$\$ 30,000$ - 39,999 & 33.0 & 29.9 & 27.3 & 13.0 & 14.3 & 3.2 \\
\hline \multirow[t]{2}{*}{$\$ 40,000$ or more } & 59.3 & 55.1 & 51.1 & 26.2 & 25.0 & 4.3 \\
\hline & \multicolumn{6}{|c|}{ (percents within source of coverage groups) } \\
\hline Total & $100.0 \%$ & $100.0 \%$ & $100.0 \%$ & $100.0 \%$ & $100.0 \%$ & $100.0 \%$ \\
\hline less than $\$ 10,000$ & $15.9 \%$ & $11.9 \%$ & $3.4 \%$ & $4.2 \%$ & $2.5 \%$ & $34.5 \%$ \\
\hline$\$ 10,000-19,999$ & $18.8 \%$ & $16.7 \%$ & $15.3 \%$ & $17.1 \%$ & $13.4 \%$ & $28.8 \%$ \\
\hline$\$ 20,000$ - 29,999 & $19.1 \%$ & $19.9 \%$ & $21.8 \%$ & $21.2 \%$ & $22.4 \%$ & $15.0 \%$ \\
\hline$\$ 30,000$ - 39,999 & $16.5 \%$ & $18.1 \%$ & $20.7 \%$ & $19.0 \%$ & $22.5 \%$ & $9.2 \%$ \\
\hline$\$ 40,000$ or more & $29.7 \%$ & $33.4 \%$ & $38.8 \%$ & $38.4 \%$ & $39.4 \%$ & $12.4 \%$ \\
\hline & \multicolumn{6}{|c|}{ (percents within income groups) } \\
\hline Total & $100.0 \%$ & $82.6 \%$ & $66.0 \%$ & $34.2 \%$ & $31.8 \%$ & $17.4 \%$ \\
\hline less than $\$ 10,000$ & $100.0 \%$ & $62.1 \%$ & $14.2 \%$ & $9.1 \%$ & $5.0 \%$ & $37.9 \%$ \\
\hline$\$ 10,000-19,999$ & $100.0 \%$ & $73.1 \%$ & $53.7 \%$ & $31.1 \%$ & $22.6 \%$ & $26.6 \%$ \\
\hline$\$ 20,000-29,999$ & $100.0 \%$ & $86.4 \%$ & $75.3 \%$ & $38.1 \%$ & $37.3 \%$ & $13.6 \%$ \\
\hline$\$ 30,000$ - 39,999 & $100.0 \%$ & $90.6 \%$ & $82.7 \%$ & $39.4 \%$ & $43.3 \%$ & $9.7 \%$ \\
\hline$\$ 40,000$ or more & $100.0 \%$ & $92.9 \%$ & $86.2 \%$ & $44.2 \%$ & $42.2 \%$ & $7.3 \%$ \\
\hline
\end{tabular}

Source : Employee Benefit Research Insitute tabulations of the March 1986 Current Population Survey 


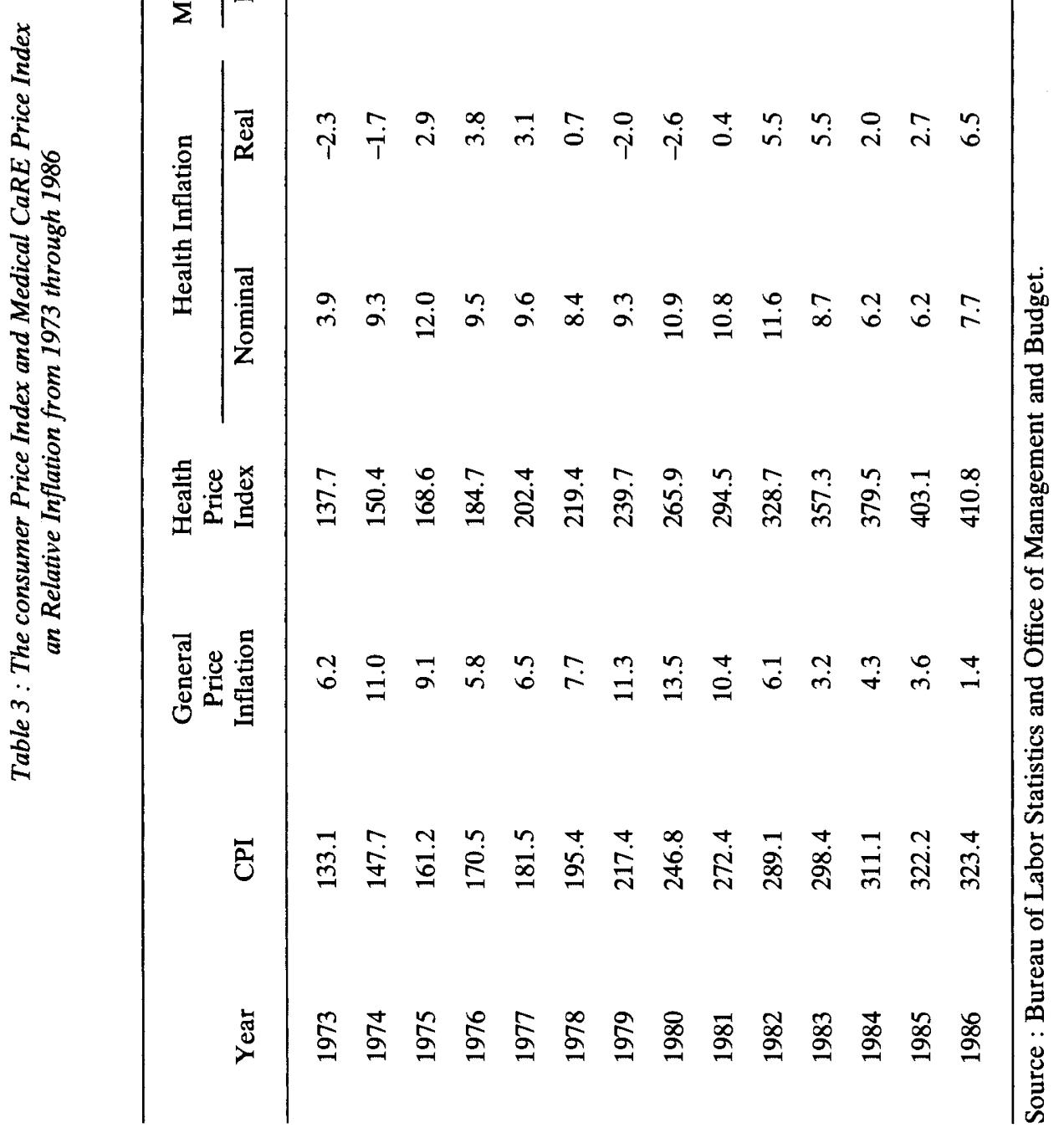




\section{The Health Inflation Juggernaut}

Attention to cost containment in the United States has been intense, but has not stopped real growth in health care costs. This may at least partially be explained by the continued growth of third party payment in the United States. And, the likely solutions to the issues of covering those without insurance, providing an insurance approach for long term care, and protecting individuals against catastrophic outlays, promise to further increase the role of third party payments.

As shown in Table 3, real increases in the health price index are at levels as high or higher than anything experienced in the last fifteen years. The index has risen in recent years at rates 2 to 3 times as great as the general consumer price index, and there is no current reason to believe that this pattern will soon abate.

\section{Changes in the Market}

The health care market in the United States has been undergoing change, driven primarly by concern over cost. Dramatic changes in the financing of health care have affected the way care is delivered. Some changes may be due to the cost-management efforts undertaken by employers, insurance carriers, and the governement. Medicare's change from cost-based, retrospective payment to diagnosis-based, prospective payment for hospital reimbursment (DRG's) also is widely considered to be a major source of change in the health care marketplace. A movement away from payment on the basis of "reasonable and customary" is following in private provision. At least partially as a result of these changes, physician practice seems to be undergoing rapid change as well. The overriding theme in the United States has become "Managed Care". The implementation of this theme has led to efforts to control both price and utilization.

Responding to this constant cost growth employers, particularly large employers, have altered the benefits they provide to their employees. They have imposed more cost sharing and greater restrictions on health service use, and expanded coverage for care alternatives that may be less costly. Employers have also moved to self-insure their plans, moving away from the purchase of protection from commercial insurers (see Tables 4 and 5). And, alternative approaches to the delivery of care have been developed.

One significant change is a movement towards the development of private national systems for managed medical delivery. An example has been the emergence of for-profit hospital care and multihospital systems. In 1983, investor-owned community hospitals operated 94,000 beds in the United States, an increase of $65 \%$ from the 57,000 beds operated in 1972. Nonprofit hospitals increased their beds by $16.4 \%$, while state and local hospitals increased their beds by $1 \%$ during the same period, according to the General Accounting Office (GAO). As of April 1985, 20\% of all nonfederal hospitals were owned or operated by investor-owned firms.

Hospitals seem to be moving toward centralization into multihospital systems. An estimated 256 such systems manage $33 \%$ of the nation's acute-care community hospitals. The GAO reports that between 1978 and 1982, the number of beds in nonprofit multihospital sytems grew at an average annual rate of $3.5 \%$, compared to $4.8 \%$ among investor-owned multihospital systems. 
Table 4 : Distribution of Health and Dental Plan Participants by Type of

Plan Funding, Establishment Size, and Industry Group, 1985

\begin{tabular}{|c|c|c|c|c|c|}
\hline & & & $\mathrm{He}$ & lan & \\
\hline & (millions) & Self-Insured $^{\mathrm{a}}$ & Insured & HMO & \\
\hline All Participants & 19.6 & $42.1 \%$ & $51,0 \%$ & $7.5 \%$ & \\
\hline $\begin{array}{l}\text { Establishment Size } \\
\text { (number of employees) }\end{array}$ & & & & & \\
\hline $100-249$ & 2.2 & $40.1 \%$ & $53.7 \%$ & $6.2 \%$ & \\
\hline $250-999$ & 7.3 & $46.1 \%$ & $49.2 \%$ & $5.8 \%$ & \\
\hline $1,000-2,499$ & 3.7 & $46.3 \%$ & $46.0 \%$ & $7.7 \%$ & \\
\hline Greater than 2,500 & 6.2 & $35.9 \%$ & $54.7 \%$ & $10.0 \%$ & \\
\hline Industry Group & & & & & \\
\hline Manufacturing & 11.1 & $39.1 \%$ & $53.8 \%$ & $7.5 \%$ & \\
\hline Nonmanufacturing & 8.5 & $45.9 \%$ & $47.5 \%$ & $7.5 \%$ & \\
\hline & & & Der & lan & \\
\hline & $\begin{array}{c}\text { Number of } \\
\text { participants } \\
\text { (millions) }\end{array}$ & Self-insured ${ }^{a}$ & Insured & HMO & Other \\
\hline All Participants & 6.2 & $44.4 \%$ & $53.7 \%$ & $1.8 \%$ & $0.1 \%$ \\
\hline $\begin{array}{l}\text { Establishment size } \\
\text { (number of employees) }\end{array}$ & & & & & \\
\hline $100-249$ & 0.6 & $43.0 \%$ & $56.8 \%$ & $0.3 \%$ & b \\
\hline $250-999$ & 2.0 & $55.3 \%$ & $44.3 \%$ & $0.4 \%$ & b \\
\hline $1,000-2,499$ & 1.4 & $49.5 \%$ & $50.0 \%$ & $0.5 \%$ & $\mathrm{~b}$ \\
\hline Greater than 2,500 & 2.1 & $30.9 \%$ & $64.2 \%$ & $4.6 \%$ & $0.3 \%$ \\
\hline Industry Group & & & & & \\
\hline Manufacturing & 3.8 & $35.3 \%$ & $63.3 \%$ & $1.4 \%$ & b \\
\hline Nonmanufacturing & 2.4 & $59.0 \%$ & $38.2 \%$ & $2.5 \%$ & $0.3 \%$ \\
\hline
\end{tabular}

Source : EBRI tabulations of the 1985 Employee Benefits Survey (U.S. Department of Labor, Bureau of Labor statistics

Note : Detail for participants in establishments with fewer than 100 employees is suppressed.

a Includes plan with some insured benefits, stop-loss insurance from a commerical carrier or Blue Cross/Blue Shield plan, and/or an Administrative-Services Only Contact.

${ }^{b}$ Less than 50,000 . 
Table 5 : Number and Percent of Participants with Coverage for Selected Health Care Expenses by Type of Plan Funding, 1985

\begin{tabular}{|c|c|c|c|c|c|c|}
\hline & \multicolumn{2}{|c|}{ Self-Insured } & \multicolumn{2}{|c|}{ Insured } & \multicolumn{2}{|c|}{ HMO } \\
\hline & $\begin{array}{l}\text { Number } \\
\text { (millions) }\end{array}$ & Percent & $\begin{array}{l}\text { Number } \\
\text { (millions) }\end{array}$ & Percent & $\begin{array}{c}\text { Number } \\
\text { (millions) }\end{array}$ & Percent \\
\hline \multicolumn{7}{|l|}{ Hospital Care } \\
\hline Covered in full & 0.2 & $2.1 \%$ & 0.4 & $3.6 \%$ & 1.4 & $96.6 \%$ \\
\hline Other coverage & 8.0 & $97.9 \%$ & 9.5 & $96.4 \%$ & $\mathbf{a}$ & $3.4 \%$ \\
\hline \multicolumn{7}{|l|}{ Intensive Care } \\
\hline Covered in full & 2.3 & $27.8 \%$ & 2.7 & $27.2 \%$ & 1.4 & $98.4 \%$ \\
\hline Other coverage & 6.0 & $72.2 \%$ & 7.2 & $72.8 \%$ & a & $1.6 \%$ \\
\hline \multicolumn{7}{|l|}{ Outpatient } \\
\hline Covered in full & 0.3 & $4.0 \%$ & 0.4 & $3.6 \%$ & 0.8 & $55.8 \%$ \\
\hline Other coverage & 7.9 & $96.0 \%$ & 9.5 & $96.4 \%$ & 0.6 & $44.2 \%$ \\
\hline \multicolumn{7}{|l|}{ Extended Care } \\
\hline Covered in full & 0.1 & $1.3 \%$ & 0.1 & $0.6 \%$ & 0.3 & $19.1 \%$ \\
\hline Other coverage & 5.1 & $61.8 \%$ & 6.7 & $68.2 \%$ & 0.8 & $57.5 \%$ \\
\hline Not covered & 3.0 & $37.0 \%$ & 3.1 & $31.2 \%$ & 0.3 & $23.4 \%$ \\
\hline \multicolumn{7}{|l|}{$\begin{array}{l}\text { Medical Treatment } \\
\text { in Office }\end{array}$} \\
\hline Covered in full & a & $0.6 \%$ & a & $0.3 \%$ & 1.0 & $69.9 \%$ \\
\hline Other coverage & 8.2 & $99.1 \%$ & 9.1 & $92.0 \%$ & 0.4 & $30.1 \%$ \\
\hline Not covered & $\mathrm{a}$ & $0.3 \%$ & 0.7 & $7.7 \%$ & NA & NA \\
\hline \multicolumn{7}{|l|}{$\begin{array}{l}\text { Diagnostic X-Ray } \\
\text { and Laboratory }\end{array}$} \\
\hline Covered in full & 0.5 & $6.5 \%$ & 2.7 & $27.1 \%$ & 1.3 & $87.6 \%$ \\
\hline Other coverage & 7.7 & $93.5 \%$ & 7.2 & $72.9 \%$ & 0.2 & $12.4 \%$ \\
\hline \multicolumn{7}{|l|}{ Prescription Drugs } \\
\hline Covered in full & 0.2 & $2.0 \%$ & 0.1 & $1.1 \%$ & 0.1 & $9.3 \%$ \\
\hline Other coverage & 8.0 & $96.7 \%$ & 9.7 & $98.1 \%$ & 1.1 & $75.6 \%$ \\
\hline Not covered & 0.1 & $1.3 \%$ & 0.1 & $0.8 \%$ & 0.2 & $15.0 \%$ \\
\hline
\end{tabular}

Source : EBRI tabulations of the 1985 Employee Benefits Survey (U.S. Department of Labor, Bureau of Labor Statistics).

${ }^{a}$ Less than 50,000 . 
In contrast to the hospital industry, the nursing home industry has always been dominated by for-profit providers. In 1984 , an estimated $81 \%$ of nursing homes were operated for profit, according to the GAO.

A second major change has been the growth in the number of alternative care facilities - or, pre paid health care options.

- The number of health maitenance organizations (HMOs) increased $1400 \%$ in 13 years, from 39 in 1971 to over 595 as of June 1986.

- In late 1984, 140 preferred provider organizations (PPOs) were operating, representing an increase of more than $300 \%$ since 1982 .

- Between 1978 and 1982 the number of freestanding emergency centers increased sevenfold, from 80 to 600 .

- By 1984 there were an estimated 125 freestanding ambulatory surgical centers.

Finally, change has occurred in response to the rising number of physicians and changes in their composition and practice. Since 1950 the number of active physicians has more than doubled, according to the GAO, rising from 220,000 in 1950 to 502,000 in 1982 . The number of physicians has increased faster than the population, so that the ratio of physicians to the population has increased by nearly $50 \%$ - from 145 per 100,000 population in 1950 to 217 per 100,000 in 1982.

Both the Graduate Medical Education National Advisory Committee (GMENAC) and the U.S. Department of Health and Human Services (HHS) predict there will be an excess supply of physicians. GMENAC's 1980 report forecasts the excess supply of physicians by 1990 will reach 70,000. The 1984 HHS report forecasts an excess of 35,000 physicians by the same year.

GMENAC also concludes that there will be an oversupply of specialists, particularly in surgery and obstetrics/gynecology, and a shortage in other specialities, such as family practice and general psychiatry.

Physicians are increasingly practicing in groups rather than solo. An increasing number of physicians in certain specialties, such as pathology and radiology, are becoming salaried employees of hospitals. Finally, more physicians are providing care on a prepaid basis and treating patients in ambulatory or outpatient settings.

\section{Managing Employer Health Costs in a Changing Market}

In 1985 , employers paid $\$ 105$ billion for health insurance. Employer payments for health insurance, which were $2.2 \%$ of wages and salaries in 1970 , were $5.4 \%$ in 1985 . Responding to this growth in payments, virtually all employers have initiated changes in their health insurance plans to contain costs. A Wyatt Company survey of group benefits in 1984 found that $97 \%$ of the 1,115 employers responding to the survey had changed their health plans in response to rising health care expenditures.

The Employee Benefits Survey (EBS) is conducted annually by the U.S. Department of Labor (DOL), Bureau of Labor Statistics (BLS). In 1985, 1,509 establishments were surveyed, with most having 250 or more full-time, permanent workers. The most common change has been increased cost sharing through copayments, deductibles, and contributory 


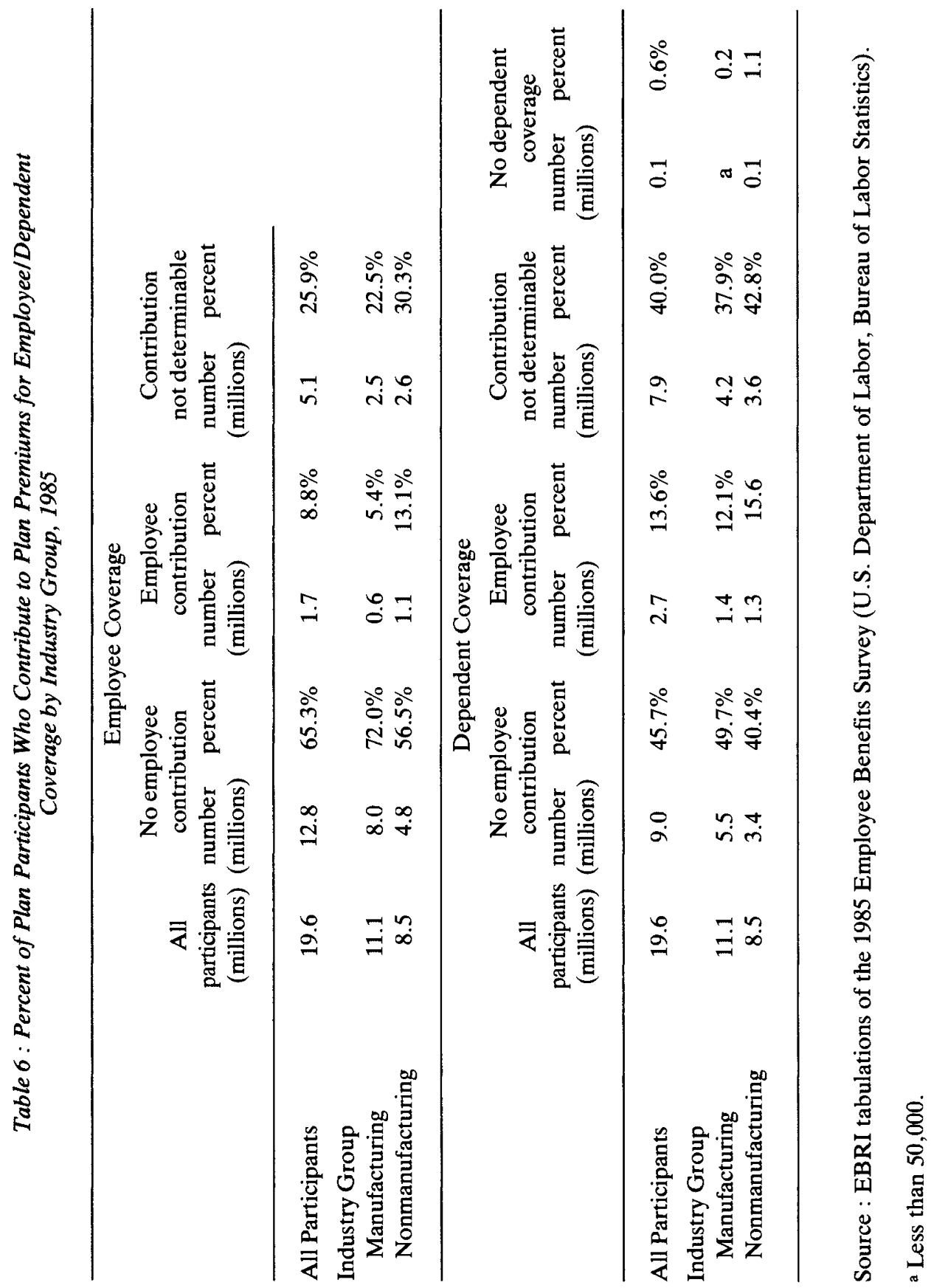


Table 7 : Percent of Plan Participants with Full or Limited Coverage for Selected Services, by Establishment Size and Industry Group, 1985

\begin{tabular}{|c|c|c|c|c|c|c|}
\hline & \multicolumn{2}{|c|}{$\begin{array}{l}\text { Hospital Room } \\
\text { and Board }\end{array}$} & \multicolumn{2}{|c|}{ Surgical Expenses } & \multicolumn{2}{|c|}{$\begin{array}{l}\text { Physician Services } \\
\text { Provided Out-of-Hospital }\end{array}$} \\
\hline & $\begin{array}{l}\text { Full } \\
\text { coverage }\end{array}$ & $\begin{array}{l}\text { Limited } \\
\text { coverage }\end{array}$ & $\begin{array}{l}\text { Full } \\
\text { coverage }\end{array}$ & $\begin{array}{l}\text { Limited } \\
\text { coverage }\end{array}$ & $\begin{array}{c}\text { Full } \\
\text { coverage }\end{array}$ & $\begin{array}{l}\text { Limited } \\
\text { coverage }\end{array}$ \\
\hline All Participants & $9.9 \%$ & $90.1 \%$ & $28.4 \%$ & $71.6 \%$ & $5.6 \%$ & $90.3 \%$ \\
\hline \multicolumn{7}{|l|}{$\begin{array}{l}\text { Establishment Size } \\
\text { (number of employees) }\end{array}$} \\
\hline $100-249$ & $7.1 \%$ & $92.9 \%$ & $19.3 \%$ & $80.7 \%$ & $4.3 \%$ & $95.7 \%$ \\
\hline $250-999$ & $8.8 \%$ & $91.9 \%$ & $24.0 \%$ & $76.0 \%$ & $5.1 \%$ & $94.6 \%$ \\
\hline $1,000-2,499$ & $11.0 \%$ & $89.0 \%$ & $26.0 \%$ & $74.0 \%$ & $4.8 \%$ & $95.0 \%$ \\
\hline 2,500 or more & $11.7 \%$ & $88.3 \%$ & $38.7 \%$ & $61.3 \%$ & $7.4 \%$ & $80.5 \%$ \\
\hline \multicolumn{7}{|l|}{ Industry Group } \\
\hline Manufacturing & $10.4 \%$ & $89.6 \%$ & $33.8 \%$ & $66.2 \%$ & $6.0 \%$ & 87.8 \\
\hline Nonmanufacturing & $9.3 \%$ & $90.7 \%$ & $21.4 \%$ & $78.6 \%$ & $5.2 \%$ & $94.7 \%$ \\
\hline
\end{tabular}

Source : EBRI tabulations of the 1985 Employee Benefits Survey

(U.S. Department of Labor, Bureau of Labor Statistics).

Note : Detail does not add to $100 \%$, since nondeterminable responses are not allocated. Detail for participants establishments with fewer than 100 employees is suppressed.

insurance premiums. This change responds to the argument that third-party insurance insulates patients from the full cost of their care, so that decisions about medical consumption are made without regard to cost. Tables 6 and 7 present data from the EBS showing the prominance of these design features.

Out-of-pocket expenditures for personal health care have declined as a percent of total health care : in 1970 , out-of-pocket payments were $40.5 \%$ of total personal health care and by 1983 had declined to $27.4 \%$.

Other cost containment initiatives are aimed at reducing unnecessary hospital use. These include coverage of preadmission testing (mandatory, voluntary, or voluntary with a financial incentive), second surgical opinions, and ambulatory surgery. Preadmission authorization, utilization review programs, and coverage of home health and hospice care have been included to reduce hospital use. Table 8 presents the EBS data on the distribution of participants with selected cost containment features.

Plans increasingly have turned to managed care and discount arrangements. Prepaid plans or health maintenance organizations, which place the provider at financial risk for the full cost of an episode of care, have become common. Individual practice associations (IPAs) have been the fastest-growing type of HMO. 


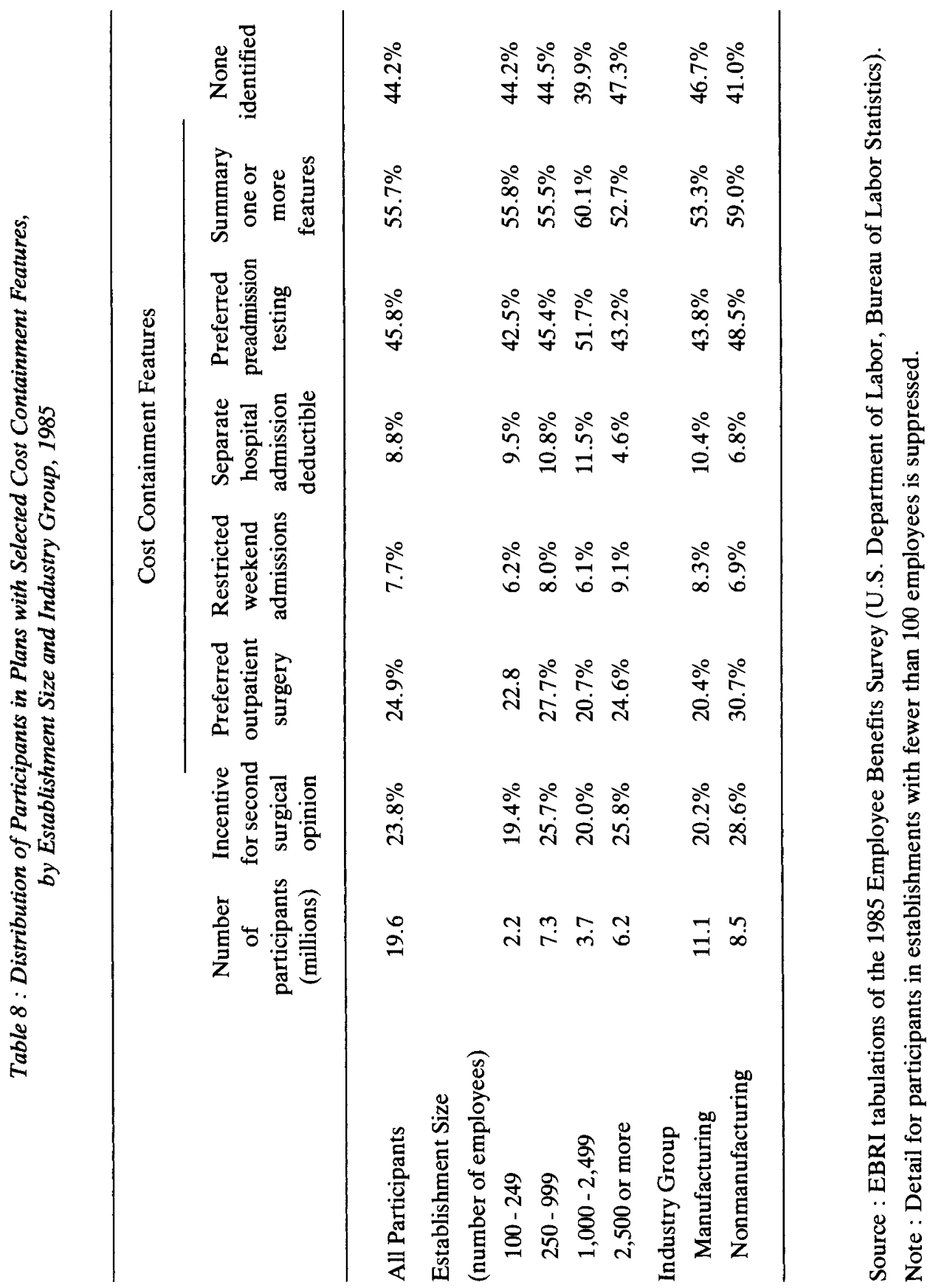


In IPAs, individual practitioners and group practices accept prepayment but are also free to accept fee-for-service reimbursement. Interstudy estimates that as of June 1983 there were 99 IPAs with enrollment of $1,888,706$. By June 1986, there were an estimated 345 serving 8,518,906 people. By comparison, in 1971 there were 39 closed-model HMOs. (Closed-model HMOs are specific sites with a staff of physicians that work for the HMO.) By June 1986, there were 250 with enrollment of over 15 million.

As of June 1986 over 330 of the HMOs were under two years age, with approximately $14 \%$ of the enrollment. The majority of members $(53 \%)$ belonged to HMOs that were over ten years old as of June 1986.

A recent phenomenon has been the growth of preferred provider organizations (PPOs). These are arrangements between providers and payers to provide fee-for-service health care at a discount. Providers obtain an increased volume of patients and sometimes faster claims processing in exchange for discounting the price of their services, and assume virtually none of the financial risk associated with care. Although payers receive the benefit of the discount, the real advantage results from selecting a provider who is relatively efficient compared to others in the area.

An emerging form of PPO is the exclusive provider organization (EPO) established by some employers. EPOs differ from PPOs in that employees must use the providers listed with the EPO, whereas a PPO merely offers a financial incentive to do so. In general, PPOs must be approved by the state insurance commissioner. PPOs established by a self-funded employer plan are not governed by the state and consequently can choose to reimburse only for the services of the exclusive providers.

Some PPOs allow workers flexibility in their choice of providers. In such a plan, an employee can select from a network of physicians who have entered into a preferred provider arrangement with the employer, or can choose a non-network physician of his or her choice. By using network providers, an employee would have little or no out-of-pocket expense; care provided outside the network may be subject to a deductible and coinsurance.

Group plans have also made administrative changes to reduce administrative cost and payment of inappropriate claims. These include claims auditing, encouraging employees to review their health care bills, and coordinating benefits when employees are covered by more than one plan.

Employers have turned to wellness progams, health fairs, and employee assistance programs to promote better health. Better health may translate into reduced absenteeism, lower health-care usage, and improved employee morale.

In many areas, business coalitions have emerged to identify problems, obtain data, and work with providers, the state government, and the state legislature to effect cost containment. According to the U.S. Chamber of Commerce's Clearinghouse on Business Coalitions for Health Action, there were about 133 coalitions with 6,600 members in 1985.

Employers have also begun to offer employees multiple plan options at different costs with different features. Federal employees, for example, were offered 380 different plan in 1986. For private employers these "flexible benefit" programs are being used as one method of reshaping employee behavior in the consumption of health services. 


\section{Social and Policy Issues in a Changing Market}

The United States devotes $10.7 \%$ of its national income to health care, making health care a \$425-billion-a-year industry. In 1970 the U.S. ranked first among industriallized nations in health care spending as a percent of national output; by 1977 , only West Germany surpassed the U.S.

Determining the appropriate level of health care spending is one of the most fundamental issues society faces. Since 1965 , explicit national health policy has had, as its goal, equal access to quality health care. Standards of equal access and quality, however, have been difficult to define. The cost of archieving further improvements in access and quality, moreover, has led to a reappraisal of the goals themselves.

Access to health care depends on the availability of providers and the ability to pay for care. Uncompensated hospital care has risen since 1978 at an estimated average rate of $10.2 \%$, reaching $\$ 6.2$ billion in 1982. EBRI tabulations of the March 1983, 1984, 1985, and 1986 Current Population Surveys indicate that the number of Americans without health insurance is increasing. In 1985, 35 million Americans (17.4\% of the population) did not have public or private insurance. This is an increase of 4.4 million individuals from two years earlier. Others have estimated that an additional 40 million Americans have inadequate insurance coverage.

Rationing health care while medical resources are idle raises new policy issues. In November 1985, average occupancy rates among community hospitals nationwide was $64.2 \%$. Hospital occupancy rates serve as a proxy for the capacity of the entire health care system, since a bed requires equipment and staff, regardless of whether it is occupied. The per-bed cost varies by hospital and region; the State of Maryland estimates that the cost of one unoccupied bed is $\$ 122,000$ per year.

One fundamental problem for assessing health care quality is the lack of data to evaluate the effectiveness of various treatments and variations among local medical protocols. For example, small-area studies of medical variations in Maine found that women age 70 or older in one geographical area were $20 \%$ likely to have undergone a hysterectomy; in another area, they were $70 \%$ likely. In Vermont, the probability that a child had a tonsillectomy ranged from $8 \%$ in one area to $70 \%$ in another. In one area of Iowa, males that had reached age 85 had a $15 \%$ chance of having had a prostatectomy, while in another area the likelihood was $60 \%$.

The Medicare Trustees have reported that the Medicare trust fund will be broke by the late 90s'. At that time the oldest of the baby boom generation will have just turned age 50 and will not yet be eligible for Medicare benefits.

For people who are now age 65 , life expectancy is 14.5 years for males and 18.7 years for females. As More and more Americans reach age 75, the need for custodial or longterm care increases. Neither Medicare nor most private insurance plans cover custodial care. Consequently, many elderly become impoverished paying for health and personal assistance care and become eligible for Medicaid. Should life expectancy continue to increase these pressures will only increase. Were progress against mortality to advance at the same rate as in the seventies, a woman born in 1984 would live until 90,12 years longer than current projections; a man would live until 81, a ten-year gain. These issues, along with eliminating the uncovered, are now at the top of the United States health policy agenda, along with management of health costs and utilization. 


\section{Meeting the Challenge of Long-Term Care}

An estimated 6.6 million Americans age 65 and older need long-term care. As the baby-boom generation ages and individuals liver longer the desire and need for long-term care will become even greater. It is projected that the number of elderly in need of longterm care will increase to 9.3 million by the year 2000 , to 12.9 million by 2020 , and to almost 19 million by 2040 .

As individuals live longer, they become more susceptible to developing chronic health conditions that require medical assistance over extended periods of time. Care for debilitating chronic conditions, or long-term care, is not covered by Medicare or most Medicare supplement (Medigap) insurance policies. Long-term care is expensive, as much as $\$ 4,500$ per month, and can deplete a lifetime's savings rapidly. Nearly two-thirds of those who enter nursing homes in the United States become improversihed in just over three months. As the nuclear family has broken down in the United States this problem has become progressively worse.

The elderly and their families have few alternatives for reducing their out-of-pocket expenditures for long-term care. Most elderly lack the resources to pay for long-term care, and private insurance, while now developing, is virtually nonexistent.

Medicaid, which pays for the poor's health in the United States, has become the only mechanism for financing long-term care. But the Medicaid program primarily covers services rendered in institutional settings, rather than home- or community-based services. Medicaid coverage poses a problem in that one must become impoverished to become eligible. Yet, unless financing mechanisms change, more pressure will be brought to bear on the program.

The Congress is now considering a catastrophic insurance program that would provide additional protection to the elderly for acute care expenses. But, the $\$ 40$ billion of higher price tag on long-term chronic care is high enough that Congress is not considering an expansion of protection that would cover long-term care.

\section{Conclusion}

The aging of the American population, the tremendous growth of the old-old (over 85) population, the extension of life expectancy, the prospect of medical advances that will extend the life-span, all serve to increase health care expenditures. The old-old growth also expands the population needing very expensive protection like long-term care.

This built in pressure for cost growth has begun to fundamentally change the United States health marketplace. Nations' frequently think of markets as dominated by buyers or sellers. Through the early 1980 s' the United States health market was dominated by the providers of health services. Today, to an increasing degree, is is dominated and being driven by the buyers and payers. Managed care growth is an example of this change - the growth of the Health Maintenance Organization being one part. 